và có thể được điều chỉnh bằng can thiệp dược lý. Chúng ta biết rằng các bất thường về lâm sàng hoặc chuyển hóa, chẳng hạn như thiếu máu, rối loạn lipid máu, tăng huyểt áp, rối loạn chức năng nội mô và đái tháo đường, là cơ sở của tỷ lệ mắc bệnh tim mạch cao. Can thiệp hợp lý bằng dược phẩm sớm và đầy đủ ở bệnh nhẩn ghép thân có thể làm giảm tỳ lệ mắc các biến chứng này.

\section{KẾT LUÂNN}

Xác định chính xác các yễu tố nguy cơ quyết định lâm sàng sinh học suy thận mạn giúp cải thiện phân loại và quản lý tốt hơn cho những người mắc bệnh thận mạn tính. Theo dõi đánh giá giai đoạn của bệnh thận mạn tính sau ghép rất quan trọng giúp đưa ra các can thiệp sớm nhằm hạn chế các biến chứng do bệnh thận mạn tính gây ra.

\section{TÀI LIÊU THAM KHẢO}

1. Stringer, S., et al., The natural history of, and risk factors for, progressive Chronic Kidney Disease (CKD): the Renal Impairment in Secondary care (RIISC) study; rationale and protocol. BMC Nephrology, 2013. 14(1): p. 95.
2. K/DOQI clinical practice guidelines for chronic kidney disease: evaluation, classification, and stratification. Am J Kidney Dis, 2002. 39(2 Suppl 1): p. S1-266.

3. United States Renal Data System Center. 2020; Available from: http://www.usrds.org/ 2002/pres/html/USRDS\%202002\%20ASN\%20Talk \%20v8\%20files/v3\%20document.htm.

4. McMurray, J. and P. Ps, KDIGO Clinical practice Guideline for Anemia in Chronic Kidney Disease. Vol. 2. 2012. 1-335.

5. Sinclair, A.M., et al., Secondary hypertension in a blood pressure clinic. Arch Intern Med, 1987. 147(7): p. 1289-93.

6. Go, A.S., et al., Chronic kidney disease and the risks of death, cardiovascular events, and hospitalization. N Engl J Med, 2004. 351(13): p. 1296-305.

7. Anavekar, N.S., et al., Relation between renal dysfunction and cardiovascular outcomes after myocardial infarction. N Engl J Med, 2004. 351(13): p. 1285-95

8. Bù̀i Văn Mạnh, Nghiên cứu lâm sàng, cận lâm sàng và một số chỉ số miễn dịch ở bệnh nhân sau ghép thận, in Nội thận tiết niệu. 2009, Học viện Quân Y.

9. Yu, M.K., et al., Risk factor, age and sex differences in chronic kidney disease prevalence in a diabetic cohort: The Pathways Study. American journal of nephrology, 2012. 36(3): p. 245-251.

\title{
KẾT QUẢ ĐIỀU TRI DÒ DICCH NÃO TUỶ DO VÕ̃ NỀN SO SAU CHẤN THƯƠNG SỌ NÃO TẠI BỆNH VIỆN VIỆT ĐỨC
}

Ngô Mạnh Hùng*

\section{TÓM TẮT}

Mục tiêu: đánh giá kết quả điều trị dò dịch não tuỷ do võ nền so sau chấn thương tai bệnh viện Viêtt Đức. Đối tượng và phương pháp nghiên cứu: nghiên cứu mô tả, hồi cứu 31 bệnh nhân được chẩn đoán và điều trị tại bệnh viện Việt Đức từ 1.2017 đến 12.2018. Kết quả: tỉ lê nam chiếm 90,3\%; tuổi trung bình : 29,03 $\pm 8,57$; tai nạn giao thông chiếm $87,1 \%$. Điều trị bảo tồn chiếm $22,6 \%$; điều trị phẫu thuât : $77,4 \%$. Có 1 trường hợp dò dịch não tuỳ tái phát sau mố. Đánh giá sau 1 năm: tốt $(93,5 \%)$; trung bình $(6,5 \%)$. Kết luận: Dò dịch não tuỷ do vỡ nền so sau chấn thương có thể được điều trị có hiệu quả, an toàn.

\section{SUMMARY \\ THE RESULTS OF TREATMENT OF CEREBROSPINAL FLUID FISTULA POSTTRAUMA IN VIET DUC HOSPITAL}

\footnotetext{
*Bệnh viện HN Việt Đức

Chịu trách nhiệm chính: Ngô Mạnh Hùng

Email: Ngomanhhung2000@gmail.com

Ngày nhận bài: 25.12.2020

Ngày phản biện khoa học: 19.2.2021

Ngày duyệt bài: 2.3.2021
}

Objective: assessment of treatment results of cerebrospinal fluid leak due to skull base fracture posttrauma in Viet Duc Hospital. Patients and method: a cross-section, descriptive, retrospective study with 31 patients who were diagnosed and treated with cerebrospinal fluid fistula in Viet-Duc Hospital from 2017 Jan to 2018 Dec. Results: Male predominance $(90.3 \%)$; mean age was 29.03; traffic accident account for $87.1 \%$. The treatment method included medical treatment $(22.6 \%)$ and surgery $(77.4 \%)$. There was a case with cerebrospinal fluid leak recurrence after surgery which was successfully treated with lumbar drainage. Year-follow-up results showed $93.5 \%$ of patients with good and $6.5 \%$ of patients with moderate. Conclusion: Cerebrospinal fluid fistula due to skull base fractures were successfully and safely treated.

\section{I. ĐẶT VẤN ĐỀ}

Tỉ lệ võ nền sọ trong các bệnh nhân võ xương sọ sau chấn thương sọ não được ước tính khoảng 20,21\% (1). Tần suất võ nền sọ sau chấn thương sọ não bao gồm $47 \%$ ở nển sọ trước, 22-37\% ở nền sọ giữa và khoảng $3 \%$ ở nền sọ sau. Dò dịch não tuỷ sau vỡ nền sọ gặp ở khoảng 1-3\% (2). Điều trị dò dịch não tuỷ do võ 
nền sọ sau chấn thương sọ não bao gồm điều trị nội khoa và ngoại khoa. Chúng tôi tiến hành nghiên cứu này với mục đích đánh giá kết quả điêu trị dò dịch não tuỷ sau chấn thương so não tại bệnh viện Việt Đức từ 1.2017 đến 12.2018

\section{II. ĐỐI TƯợNG VÀ PHƯƠNG PHÁP NGHIÊN CứU}

Nghiên cứu hồi cứu tất cả các bệnh nhân được chẩn đoán dò dịch não tủy do vỡ nền sọ sau chấn thương sọ não, được khám và điều trị tại khoa PTTK 2 bệnh viện Việt Đức từ 1.2017 đến 12.2018.

Tiêu chuẩn lựa chơn bệnh nhân:

- Được chẩn đoán là dò dịch não tủy do võ nền sọ sau CTSN

- Có đầy đủ hồ sơ bệnh án

Tiêu chuân loai trừ: Bệnh nhân từ chối không tham gia nghiên cứu.

Phương pháp nghiên cứu: mô tả, hồi cứu.

Số liệu được thu thập từ hồ sơ bệnh án: đặc điểm chung của bệnh nhân, nguyên nhân CTSÑ, phương pháp điều trị và kết quả điều trị.

Khám lại bệnh nhân sau 1 năm, bao gồm khám lâm sàng, chụp cắt lớp vi tính sọ não. Bệnh nhân được xếp thành 3 nhóm:

- Tốt: Hết dò dịch não tuỷ, không có di chứng phẫu thuật

- Trung bình: hết dò dịch não tuỷ, di chứng nhẹ nhưng bệnh nhân vẫn quay lại với công việc hàng ngày

- Xấu: còn dò dịch não tuỷ, có di chứng khiến cho bênh nhân không tự chăm sóc được bản thân, cần có người hỗ trợ, hoặc tử vong/tàn phế

Số liệu được làm sạch, xử lý theo các thuật toán thống kề thông thường theo phần mềm SPSS 20.0

\section{KẾT QUẢ NGHIÊN CỨU}

Nghiên cứu của chúng tôi được tiến hành từ 1.2017 đến 12.2018 tại trung tầm phẫu thuật Thần kinh, bệnh viện Việt Đức, có 31 bệnh nhẩn đủ các tiêu chuẩn nghiên cứu.

3.1 Đặc điểm chung của nhóm bệnh nhân nghiên cứu. Nhóm nghiên cứu của chúng tôi có $90,3 \%$ nam giới $(9,7 \%$ nữ). Tuổi trung bình của nhóm nghiên cứu là $29,03 \pm 8,57$, thay đổi từ 19-61 tuổi. Nhóm tuối gặp nhiêuu nhất là $21-40(80,6 \%)$

Nguyên nhân thường gặp nhất của chấn thương sọ não là tai nạn giao thông $(87,1 \%)$, tiép đó là tai nạn lao động $(9,7 \%)$ và tai nạn sinh hoạt $(3,2 \%)$.

Chụp cắt lớp vi tính là phương tiện chẩn đoán hình ảnh thường quy được sử dụng trong nghiên cứu. Có $80,1 \%$ số bệnh nhân có võ̃ tầng trước nền sọ, và $19,9 \%$ vỡ tầng giữa nền sọ. Không có bệnh nhân nào trong nghiên cứu có vỡ tầng sau nền so.

\subsection{Phương pháp điêu trị}

Bảng 1. Phương pháp điều trị dò dịch não tuý

\begin{tabular}{|c|c|c|}
\hline Phương pháp điêuu trị & Tần suất & Tỷ lệ\% \\
\hline Bảo tô̂n & 7 & 22,6 \\
\hline Bảo tồn + Phâ̂u thuật & 15 & 48,4 \\
\hline Phấu thuật & 9 & 29,0 \\
\hline Tống số & $\mathbf{3 1}$ & $\mathbf{1 0 0 \%}$ \\
\hline
\end{tabular}

Trong nhóm nghiên cứu của chúng tôi, có 7 trường hợp được điều trị bảo tồn. 24 trường hợp được điều trị phẫu thuật, trong đó có 9 trường hợp chỉ định mổ ngay sau khi có chẩn đoán. 15 trường hợp chỉ định phẫu thuật sau khi điều trị bảo tồn không có kết quả.

Trong số 24 bệnh nhân được điều trị phẫu thuật, 3 trường hợp (12,5\%) được điều trị theo phương pháp nội soi và 21 trường hợp $(87,5 \%)$ điều trị phấu thuật mổ mở sọ.

Bàng 2. Sốlượng lố dì/rách màng cứng xác định trong phấu thuật $(n=24)$

\begin{tabular}{|c|c|c|}
\hline Số lượng lố rò & Tần suất & Tỷ lệ\% \\
\hline 1 lố rò & 17 & 70,8 \\
\hline Nhiều lố rò & 7 & 29,3 \\
\hline Tổng số & $\mathbf{2 4}$ & $\mathbf{1 0 0}$ \\
\hline
\end{tabular}

Trong số 24 trường hợp điều trị phấu thuật, trong khi mổ đánh giá đặc điểm của các lổ rò/rách màng cứng, chúng tôi có các kết quả chi tiết sau:

$$
\text { - } 17 \text { bệnh nhân chỉ có một lỗ dò }(70,8 \%) ; 7
$$
trường hợp có nhiều hơn 1 lố dò $(29,3 \%)$

- Có 18 trường hợp lỗ dò/rách màng cứng chỉ nằm ở một bên (bên phải hoặc trái), chiếm $75 \%$. $25 \%$ số bệnh nhân còn lại, lỗ dò/rách màng cứng nằm ở cả hai bên.

\section{Bảng 3. Biến chứng sau phẫu thuật}

\begin{tabular}{|c|c|c|}
\hline Biến chứng sớm & Số lượng & Tỉ lệ\% \\
\hline Rò DNT & 1 & 4,1 \\
\hline Viêm màng não & 2 & 8,3 \\
\hline
\end{tabular}

Sau điều trị, nghiên cứu của chúng tôi có 1 trường hợp dò tái phát sau điều trị phẫu thuật, cân phải điều trị bảo tồn (đặt dẫn lưu dịch não tuỷ thắt lưng) bệnh nhân có kết quả tốt.

Có 2 bệnh nhân có biến chứng viêm màng não sau phẫu thuật. Điều trị nội khoa cho kết quả tốt. Bệnh nhẩn không dấu hiệu của viêm màng não và dò dịch não tuỷ khi ra viện.

Bảng 4. Kêt quả điều trị sau 1 năm

\begin{tabular}{|c|c|c|}
\hline Kết quả điều trị & Số lượng & Tỷ lệ \\
\hline Tốt & 29 & 93,5 \\
\hline Trung Bình & 2 & 6,5 \\
\hline
\end{tabular}




\begin{tabular}{|c|c|c|}
\hline Xấu & 0 & 0 \\
\hline Tổng & $\mathbf{3 1}$ & $\mathbf{1 0 0}$ \\
\hline
\end{tabular}

Khám lại bệnh nhân sau 1 năm, bao gồm khám lâm sàng tình trạng dò dịch não tuỷ, đánh giá lâm sàng viêm màng não và làm xét nghiệm máu/dịch não tuỷ nếu nghi ngờ có viêm màng não. Chụp cắt lớp vi tính để chẩn đoán các nghi ngờ dò dịch não tuỷ. Chúng tôi có 93,5\% số bệnh nhân có kết quả tốt; $6,5 \%$ số bênh nhân còn phàn nàn đau đâu, đau vùng mổ khi thay đổi thời tiết. Chup cắt lớp vi tính và xét nghiêm các bệnh nhân này không phát hiện dò dịch não tuỷ tái phát cũng như viêm màng não.

\section{BÀN LUÂN}

4.1 Đặc điểm chung của nhóm bệnh nhân. Trong nhóm nghiên cứu gồm 31 bệnh nhân của chúng tôi, tuổi trung bình của bệnh nhân là 29 tuổi, tương đương với các kết quả của Hoàng Văn Hiếu (3) và Nguyễn Thế Hào (4). Lứa tuối thường gặp nhất là 21-40 tuổi phù hợp với nguyên nhân chấn thương là tai nạn giao thông vì đây là lứa tuối sử dụng các phưởng tiện giao thông cá nhân nhiều nhất.

4.2. Phương pháp điều trị. Điều trị bảo tồn (bao gồm điều tri nôi khoa, đăt tư thế bênh nhân đúng và đặt dẫn lưu dịch não tuỷ thắt lưng) được tiến hành ở hâuu hết các bệnh nhân (22 bênh nhân) dò dịch não tuỷ mới được chẩn đoán trong nghiên cứu của chúng tôi. Chỉ có 9 bệnh nhân trong nghiên cứu của chúng tôi được chỉ định điêuu trị phẩu thuật ngay sau khi có chẩn đoán, là do đường rách lớn, mảnh xương di lệch lớn, xuyên vào não.

Trong số 22 bệnh nhân được điêu trị bảo tôn ban đầu, có 7 bệnh nhân $(22,6 \%)$ hết dò dịch não tuỷ và 15 bệnh nhân cân phải phẫu thuật. Kết quả của chúng tôi thấp hơn rất nhiều so với của Bell và cộng sự (5) (85\% hết dò) hay Mincy (6). Tuy nhiên, khi so với các kết quả của các tác giả trong nước, chúng tôi thấy kết quả tương đương với Nguyễn Thế Hào (4) và Hoàng Văn Hiếu (3). Có một số lý do có thể giải thích cho sự khác biệt với các tác giả nước ngoài cũng như sự tương đờng với các tác giả trong nước như sau: (1) nguyên nhân chấn thương so não ở các nghiên cứu nước ngoài chủ yếu là ngã và tai nạn thể thao $(5,6)$, đặc điểm là đường vỡ ít di lệch, không có mảnh xương võ rời. Trong khi đó nguyên nhân chấn thương chính của nhóm bệnh nhân trong nghiên cứu của chúng tôi là tai nạn giao thông, mức độ nặng hơn rất nhiều so với các tác giả trên.

Điều trị phẫu thuật trong nghiên cứu của chúng tôi được chỉ định khi xác định lỗ rò/rách màng cứng lớn, hoặc có mảnh xương nền sọ võ di lệch khiến cho đường vỡ xương rộng. Chỉ định mổ cũng được đăt ra khi điều trị bảo tồn không có kết quả. Tuỳ thuộc vào vị trí của đường võ̃ xương và đường dò dịch não tuỷ mà có thể tiến hành phẫu thuật nội sọ (qua xoang bướm, xoang sàng): 3 trường hợp $(12,5 \%)$ hay phẫu thuâtt mở nắp sọ: $87,5 \%$. Chỉ định phẫu thuật nội soi ít gặp trong nghiên cứu của chúng tôi bởi đặc điểm của đường rách màng cứng sau chẩn thương thường phức tạp và khó kiểm soát hơn rất nhiều so với dò dịch não tuỷ sau phẫu thuật. Hầu hết các đường rách màng cứng thường rộng hơn so với đường võ xương, vì vậy khả năng bít đường dò với phẫu thuật nội soi hạn chế hơn nhiêu so với phấu thuật mở nắp sọ.

Trong phẫu thuật mở nắp sọ, chúng tôi thường tiến hành mở nắp so trán hai bên cho các phẫu thuật võ̃ tầng trước nền so. Ngoài việc mở rộng rãi để đánh giá toàn diện đường vỡ xương cũng như đường rách màng cứng, mở nắp sọ trán hai bên còn giúp kiểm tra và đánh giá các đường võ xương cũng như rách màng cứng tiềm tàng, không có biểu hiện lâm sàng (bảng 2).

Biến chứng dò dịch não tuỷ tái phát sau điều trị phẫu thuật cũng là một trong các biến chứng hay gă̆p sau phẫu thuât. Chúng tôi có 1 trường hợp $(4,1 \%)$ dò dịch não tuỷ tái phát sau mổ ngày thứ 4 và được điều trị thành công với đặt dẩn lưu dịch não tuỷ thắt lưng. Pinan Liu và công sự (7) cũng công bố tỉ lệ dò dịch não tuỷ tái phát là $7,5 \%$.

Viêm màng não sau mổ có thể là biến chứng của phẫu thuật hoặc là hậu quả của tình trạng dò dịch não tuỷ. Điều trị nội khoa là chỉ định được áp dụng cho các trường hợp này. Dựa trên kết quả kháng sinh đồ và khi loại bỏ nguyên nhân (dò dịch não tuỷ), cả 2 trường hợp viêm màng não trong nghiên cứu của chúng tôi đều điêu trị khỏi sau 14 ngày.

4.3. Kết quả điều trị. Tiến hành khám lại bệnh nhân sau 1 năm, chúng tôi có $93,5 \%$ số bểnh nhân có kết quả tốt và $6,5 \%$ số bệnh nhân còn một số phàn nàn nhỏ sau điều trị. Phàn nàn chủ yểu của bệnh nhân là đau đầu khi thay đổi thời tiết. Không có bệnh nhân nào có triệu chứng của dò dịch não tuỷ tái phát và viêm màng não tái phát. Kết quả này của chúng tôi cũng tương đương với của Nguyễn Thế Hào (4)

\section{KẾT LUÂN}

Qua nghiên cứu 31 bệnh nhân đã được chẩn đoán và điều trị dò dịch não tuỷ do vỡ nền sọ 
sau chấn thương sọ não tại bệnh viện Việt Đức, chúng tôi thu được kết quả như sau: tỉ lệ nam chiếm phần lớn $(90,3 \%)$; tuổi trung bình của nhóm nghiên cứu là $29,03 \pm 857$. Điều trị bảo tồn chiếm 22,6\%; điêu trị phẫu thuật chiếm $77,4 \%$. Có 1 trường hợp dò dịch não tuỳ tái phát sau mổ, điều trị thành công với đặt dẫn lưu dịch não tuỷ thắt lưng. Đánh giá kết quả sau 1 năm có $93,5 \%$ tốt; $6,5 \%$ kết quả trung bình. Không có dò dịch não tuỷ tái phát, viêm màng não cũng như tử vong liên quan đến điều trị.

\section{TÀI LIÊU THAM KHẢO}

1. Michael Lemole, Behbahani M. Retrospective Study of Skull Base Fracture: A Study of Incidents, Complications, Management, and Outcome Overview from Trauma-One-Level Institute over 5
Years. J Neurol Surg B Skull Base. 2013(74):A239.

2. Schlosser RJ, Bolger WE. Nasal cerebrospinal fluid leaks: critical review and surgical considerations. Laryngoscope. 2004;114(2):255-65.

3. Hiếu HV. Nghiên cứu chẩn đoán và xử trí tổn thương xoang hơi trán trong chấn thương sọ não: Đai hoc Y Hà nôii 2004.

4. Hào NT. Chẩn đoán và điêuu trị rò dịch não tủy do võ̃ tânng trước nền sọ sau chân thương. $Y$ học Việt nam. 2010;3:30-4.

5. Bell RB, Dierks EJ, Homer L, Potter BE. Management of cerebrospinal fluid leak associated with craniomaxillofacial trauma. J Oral Maxillofac Surg. 2004;62(6):676-84.

6. Mincy JE. Posttraumatic cerebrospinal fluid fistula of the frontal fossa. J Trauma. 1966;6(5):618-22.

7. Liu P, Wu S, Li Z, Wang B. Surgical strategy for cerebrospinal fluid rhinorrhea repair. Neurosurgery. 2010;66(6 Suppl Operative):281-5; discussion 5-6.

\section{MỐI LIÊN QUAN GIỮA ĐA HİNH GEN VKORC1-1639G >A, 1173C>T, CYP2C9*3 VÀ LIỀU THUỐC ACENOCOUMAROL Ở BÊNH NHÂN TIM MẠCH TẠI BÊ̂NH VIÊ̂N TRUNG ƯƠNG THÁI NGUYÊN}

Phạm Thị Thùy¹, Bùi Thị Thu Hương ${ }^{1}$, Nguyễn Thị Hương

\section{TÓM TẮT}

Ở bênh nhân mắc các bênh lý về tim mạch có nguy cơ cao hình thành huyết khối thì việc dùng thuốc chống đông như acenocoumarol là hết sức cần thiết. Có nhiều yếu tố ảnh hưởng đễn sự thay đổi liều giữa các cá thể người bệnh trong đó có đặc điểm về di truyền. Do vâyy, nghiên cứu này được thưc hiên với mục tiêu xác định mối liên quan giữa các đảa hình gen VKKORC1-1639G >A, 1173C>T và CYP2C9*3 với liêu thuốc acenocoumarol ở bệnh nhân tim mạch tại bệnh viện Trung ương Thái Nquyên. Phươnq pháp: Xác đinh tần số alen, kiểu gen VKORC1-1639G >A, 1173C >T, CYP2C9*3 bằnq kỹ thuật PCR-CTPP và giải trình tư qen. Kết quả: Tỷ lê alen biến dị của VKORC1$1639 \mathrm{G}>\mathrm{A}, 1173 \mathrm{C}>\mathrm{T}$ và $\mathrm{CYP} 2 \mathrm{C} 9 * 3$ lần lướt là 0,911 , 0,901 và 0,023 . Có mối liên quan qiữa tuổi, chỉ số BMI và đa hình qen VKORC1-1639G $>A, 1173 C>T$ với liêu thuốc chống đông acenocoumarol ở bệnh nhân mắc các bệnh lý về tim mạch tại bệnh viện Trung ương Thái Nguyên $(p<0,05)$.

Tư khóa: Acenocoumarol, đa hình gen VKORC1, CYP2C9.

\section{SUMMARY}

RELATIONSHIP BETWEEN VKORC1-

${ }^{1}$ Trường đại học Y Dược Thái Nguyên

${ }^{2}$ Bệnh viện Trung ương Thái Nguyên

Chiu trách nhiệm chính: Pham Thi Thùy

Email: phamthuydhy2612@gmail.com

Ngày nhận bài: 28.12.2020

Ngày phản biện khoa học: 25.2.2021

Ngày duyệt bài: 4.3.2021

\section{G >A, 1173C > T, CYP2C9*3 AND ACENOCOUMAROL DOSAGE IN CARDIOVASCULAR DISEASE PATIENTS IN THAI NGUYEN CENTRAL HOSPITAL}

In patients with cardiovascular diseases at high risk of thrombosis, the use of anticoagulants such as acenocoumarol is essential. There are many factors influencing the dose variation between individual patients, including genetic traits. Therefore, this study was carried out with the aim of determining the association between the genetic polymorphisms VKORC1-1639G >A, 1173C>T and CYP2C9*3 with the dose of acenocoumarol in cardiovascular patients at Thai Nguyen Central Hospital. Method: Determination of allele frequency, genotype VKORC1-1639G $>A$, $1173 \mathrm{C}>\mathrm{T}$ and CYP2C9*3 by PCR-CTPP technique and genetic sequencing. Results: The rates of allele variation of VKORC1-1639G $>A, 1173 \mathrm{C}>\mathrm{T}$ and CYP2C9*3 were $0.911,0.001$ and 0.023 , respectively. There was an association between, age, BMI and gene polymorphism VKORC1-1639G $>A, 1173 C>T$ and acenocoumarol dose in patients with cardiovascular diseases at Thai Nguyen Central Hospital $(p<0,05)$.

Key words; Acenocoumarol, VKORC1, CYP2C9 polymorphisms

\section{I. ĐẶT VẤN ĐỀ}

Thuốc chống đông acenocoumarol được sử dụng trên lâm sàng trong phòng ngừa và điều trị huyết khối ở sau thay van tim nhân tạo, rung tâm nhĩ, huyết khối tĩnh mạch sâu... [1]. Thuốc có những nhược điểm mà các nhà lâm sàng cần cân nhắc như giới hạn điều trị hẹp gây nguy cơ 